УДК 159.955:37.016:94.327(477) «1932/1933»

DOI: 10.37026/2520-6427-2021-108-4-105-109
Руслана ДАВИДЮК,

доктор історичних наук, професор,

професор кафедри історії Украӥни

Рівненського державного

гуманітарного університету,

м. Рівне, Украӥна

ORCID: 0000-0003-0485-5121

e-mail:davrus63@gmail.com

Віталіна ДАНИЛЬЧУК,

кандидат історичних наук, доцент,

доцент кафедри суспільно-гуманітарної освіти

Рівненського обласного інституту

післядипломної педагогічної освіти,

м. Рівне, Украӥна

ORCID: 0000-0002-7176-7386

e-mail:vitalina.-@ukr.net

\title{
РОЗВИТОК КРИТИЧНОГО МИСЛЕННЯ УЧНІВ У ПРОЦЕСІ ВИВЧЕННЯ ТЕМИ «ГОЛОДОМОР 1932-1933 РОКІВ В УКРАЇНІ»
}

\begin{abstract}
Анотація. У статті окреслено напрями розвитку критичного мислення школярів у прочесі вивчення теми «Голодомор 1932-1933 років в Україні». Звернено увагу на те, щчо в шкільному курсі історії проблематика Голодомору є важливою для формування ключових $i$ предметних компетентностей учнів, їхньої активноі громадянської позииії, поваги до прав і свобод людини та вміння мислити критично. Зважаючи на зміну підходів щчодо викладання означеної теми, окреслено ключові аспекти, які варто враховувати задля належного осмислення тогочасних процесів, щуо відбувалися в Украӥні та світі.

Наголошено, шзо тему Голодомору необхідно вивчати не лише як велику трагедію украӥнського народу, а й як історію його боротьби, підтримки і взаємодопомоги, зокрема важливо порушувати питання інформації та пропаганди у період 1932-1933 років, проявів доброчинності, незламності в екстремальних, загрозливих для життя умовах; називати якомога більше імен та прізвищ людей, які не лише зуміли пережити ті часи, а також допомагали зробити ие іншим, доносили світу правду про трагедію Голодомору загалом та ситуаиію, щзо склалася у 1932-1933 роках в Україні, зокрема.
\end{abstract}

Задля розуміння політики організації голоду в 30-х роках XX сm. та ії наслідків необхідно застосовувати комплекс відповідних методичних інструментів розвитку критичного мислення, покликаних створити умови для усвідомлення учнями матеріалу, щзо вивчається, систематизації отриманих знань, уміння віднайти необхідну інформачію, оцінити ії правдивість, відстоюючи власну точку зору та обтрунтовуючи ї̈, приймати виважені рішення.

Запропоновано приклади використання методів $i$ прийомів розвитку критичного мислення в ході вивчення теми Голодомору 1932-1933 років, як-от: робота з різними видами текстів (спогадами, щоденниками очевидиів / учасників подій 1932-1933 років, документами, публікаціями у тогочасній пресі); постановка запитань; навчальна дискусія та рефлексія; наочні методи організації інформачії. Творче використання представленого інструментарію дозволить педагогам досягти значних результатів у розвитку критичного мислення учнів та підвищенні рівня їхніх навчальних досягнень.

Ключові слова: критичне мислення, метод, прийом, Голодомор 1932-1933 років, інформація, пропаганда.

\author{
Ruslana DAVYDYUK, \\ Doctor of Historical Sciences, \\ Associate Professor, Professor, \\ Rivne State Humanities University, \\ Rivne, Ukraine \\ ORCID: 0000-0003-0485-5121 \\ e-mail:davrus63@gmail.com \\ Vitalina DANYLCHUK, \\ Candidate of Historical Sciences, \\ Associate Professor, \\ Associate Professor of Humanities and \\ Social Education Department, \\ Rivne Regional Institute of \\ Postgraduate Pedagogical Education, \\ Rivne, Ukraine \\ ORCID: 0000-0002-7176-7386 \\ e-mail:vitalina.-@ukr.net
}




\section{DEVELOPMENT OF STUDENTS CRITICAL THINKING DURING STUDYING THE TOPIC «HOLODOMOR OF 1932-1933 IN UKRAINE»}

\begin{abstract}
The article outlines the ways of development of critical thinking of student's in the study of the topic "Holodomor of 1932-1933 in Ukraine». Attention is paid to the fact that the school course of history Holodomor issues is important for the formation of key competencies and subject the students, their active citizenship, respect for human rights and freedoms and the development of critical thinking skills. Given the changing approaches to teaching the topic outlines key issues, which should focus for the proper understanding of contemporary processes taking place in Ukraine and the world.

Emphasized that Holodomor must be studied not only as a great tragedy, but also a history of the Ukrainian struggle and mutual support. It is important to raise the topic of information and propaganda during the Holodomor of 1932-1933, manifestations of charity, steadfastness in extreme, life-threatening conditions, and so on. It is necessary to name as many names and surnames of people who managed to survive the times that helped others do it, who told the world the truth about the situation in Ukraine in 1932-1933 and the tragedy of the Holodomor and so on.

In order to understand the policy of organizing the famine of the 1930s and its consequences, it is necessary to apply a set of appropriate methodological tools for the development of critical thinking, designed to create conditions for students to understand the material studied, systematize, generalize knowledge, ability to find necessary information and defend their own point of view, justifying it, make informed decisions.
\end{abstract}

As part of our article offers some examples of methods and techniques of critical thinking in the study of Holodomor 1932-1933. Among them: the methods of work with different kinds of texts (memoirs, diaries of eyewitnesses / participants of events that took place in the 30s of the twentieth century, documents, publications in the press of that time), visual methods of information organization; asking questions; educational discussion and reflection. The creative use of the tools will allow teachers to achieve good results in the development of critical thinking of students and improve their learning achievements.

Key words: critical thinking, method, technique, Holodomor of 1932-1933, information, propaganda.

Постановка проблеми. Трансформаційні процеси, що відбуваються сьогодні в освіті, актуалізують питання «формування всебічно розвиненої, здатної до критичного мислення особистості, патріота з активною життєвою позицією, інноватора, здатного змінювати навколишній світ та вчитися впродовж життя» (Концепція «Нова українська школа», 2016, с. 6), тобто якісна освіта нині нерозривно пов'язана з розвитком критичного мислення.

У Законі України «Про освіту» (2017) зазначається, що вміння критично і системно мислити є наскрізним в усіх ключових компетентностях, необхідних кожній сучасній людині для успішної життєдіяльності. Відповідно формування і розвиток критичного мислення $є$ важливою умовою реалізації компетентнісного потенціалу кожної освітньої галузі.

Вагома роль у цьому процесі належить шкільній історичній освіті, реалізація мети якої здійснюється через розвиток основних складових історичної свідомості, зокрема вміння оцінювати історичні події, явища та процеси під різними кутами зору, знаходити оптимально ефективні способи розв'язання проблем та ін., що покладені в основу творчого, критичного мислення. Критерієм оцінки навчальної діяльності учнів є вміння узагальнювати, аналізувати, активно використовуючи інформацію в нестандартних ситуаціях, самостійно здобувати знання, вести дослідницько-пошукову роботу тощо (Програми для загальноосвітніх навчальних закладів. Історія України. Всесвітня історія. 5-11 класи, 2018).

Значимість розвитку критичного мислення дітей та учнівської молоді у процесі навчання історії посилюється ще й з огляду на стрімкий інформаційний потік, поширювану його стереотипність, маніпулятивність, намагання вплинути на свідомість людей і спрямувати хід їхніх думок у визначене русло. У зв'язку з цим важливою складовою освітнього процесу має бути використання різноманітних методів і прийомів розвитку критичного мислення.

Аналіз наукових досліджень і публікацій. Історіографічний аналіз проблеми розвитку критичного мислення учнів у процесі навчання історії засвідчив, що цей напрям нині є особливо актуальним і привертає увагу багатьох українських та закордонних учених і педагогів. В означеному контексті варто відзначити праці К. Баханова (2008), О. Пометун, I. Сущенка (2016), С. Терно (2011), В. Курилів (2008) та ін., які вміщують не лише теоретичні аспекти розвитку критичного мислення, а й відповідний методологічний інструментарій, доцільний для використання на заняттях з історії. Однак, незважаючи на значні здобутки, недостатньо розробленими залишаються питання, присвячені особливостям розвитку критичного мислення в ході вивчення окремих складних тем, до яких належить і тематика Голодомору 1932-1933 років в Україні.

Мета статті - окреслити напрями розвитку критичного мислення учнів у процесі вивчення теми «Голодомор 1932-1933 років в Україні»; запропонувати навчально-методичні матеріали з цієї тематики.

Виклад основного матеріалу дослідження. У шкільному курсі історії важливою для формування ключових і предметних компетентностей учнів (здобувачів освіти), їхньої активної громадянської позиції, поваги до прав і свобод людини та розвитку критичного мислення є тематика Голодомору 1932-1933 років в Україні, підходи до викладання якої нині зазнають суттєвих змін.

Задля розуміння низки тематичних аспектів політики організації голоду в $30-\mathrm{x}$ роках XX ст. та їі 
наслідків необхідно застосовувати комплекс відповідних методичних інструментів із розвитку критичного мислення, покликаних створити умови для розуміння учнями матеріалу, що вивчається, систематизації отриманих знань, уміння віднайти необхідну інформацію, оцінити її правдивість, відстоюючи власну точку зору та обгрунтовуючи іiі, приймати виважені рішення.

Основними методами і прийомами розвитку критичного мислення є: методи роботи з різними видами текстів; наочні методи організації інформації; постановка запитань; навчальна дискусія та методи рефлексії. Свідоме використання цих методів дозволить педагогам досягти значних результатів у розвитку самостійного мислення школярів та підвищенні рівня їхніх навчальних досягнень (Навчаємо мислити критично, 2016, с. 14).

У межах нашого дослідження пропонуємо деякі приклади використання означених методів і прийомів розвитку критичного мислення у процесі вивчення тематики Голодомору 1932-1933 років.

Із метою належного осмислення процесів, що відбувалися в тогочасній Україні, варто зосереджувати увагу школярів на тому, що Голодомор - це не лише велика трагедія українського народу, а й історія його боротьби, підтримки і взаємодопомоги. У зв'язку з цим необхідно називати якомога більше імен та прізвищ тих людей, які в екстремальних умовах, навіть ціною власного життя, наважувалися чинити спротив, намагалися врятувати / рятували своїх знайомих, близьких, а подекуди й зовсім чужих людей.

В означеному контексті дієвою $\epsilon$ робота зі спогадами, щцоденниками очевидиів / учасників подій, що відбувалися у 30 -х роках XX ст., та доброчинців - учителів, лікарів, священників, голів сільських рад, селян та інших, котрі, попри смертельну загрозу, рятували людей в роки Голодомору (Людяність у нелюдяний час, 2018; Репресовані щоденники, 2018). Означені джерела містять унікальну інформацію про події через сприйняття окремої людини, вони персоналізують історичний досвід та переміщують масштабні суспільні процеси у площину особистісного переживання та сприйняття очима конкретного учасника. Так, крізь призму спогадів, на досвіді окремої людини, можна простежити стратегії виживання в надскладних умовах, розкрити вплив згаданого життєвого етапу на подальшу долю, з'ясувати низку важливих аспектів життя соціуму за тих чи інших історичних обставин тощо.

У ході заняття, наприклад, для роботи з текстами, можна використати метод читання з маркуванням, який допоможе проаналізувати, усвідомити текст, виділити в ньому головне, відоме / невідоме, цікаве, незрозуміле. Маркувати можна за допомогою позначок у тексті: «+» (відоме); «-» (те, що суперечить уявленням учнів і $є$ для них новим); «!» (цікаве й неочікуване); «?» (незрозуміле, таке, що викликає бажання дізнатися про це більше). Також можна складати таблицю маркування. Важливим етапом роботи $є$ обговорення результатів маркування (Навчаємо мислити критично, 2016, с. 19-20)

Приклади Людей правди (Малкольм Маггерідж, Гарет Джонс, Ріа Клаймен та ін.), історії їхнього життя дозволять учням розкрити значимість фейків $\mathrm{i}$ пропаганди в інформаційному просторі та особливості їх розпізнавання, шляхи подолання знецінення суспільно активної людини, а також допоможуть усвідомити потребу довіри, взаємопідтримки і дружби.

Одним із варіантів роботи з учнями в цьому напрямі може слугувати перегляд тематичних відеоматеріалів із подальшим їх обговоренням про журналістів, які робили все для того, щоб світ дізнався про трагедію Голодомору 1932-1933 років в Україні, наприклад, відеоряд «Гарет Джонс - журналіст, який першим розкрив правду про Голодомор 33-го року», фільм, трейлери до фільму «Ціна правди» (Гарет Джонс, 2017; Ціна правди, 2019) тощо. Після перегляду надзвичайно важливою є рефлексія (у вигляді індивідуальної роботи, роботи в парах, групах, дискусії, в письмовій чи усній формах).

Можна також скористатися прийомом «Портретна галерея» і підготувати виставку (офлайн чи онлайн), яка демонструє життя і діяльність людей, котрі доносили правду про Голодомор. Через індивідуальну або групову роботу залучаємо учнів до реалізації відповідного дослідницького проєкту «Люди правди: історії, яких ми не знали» із подальшою його презентацією на різних рівнях. У зв'язку з цим варто використовувати тематичні матеріали Українського інституту національної пам'яті, що стосуються тих людей, які не боялися говорити та писати про Голодомор навіть у часи, коли це могло коштувати їм життя (Люди правди, 2015).

Проблематику інформації та пропаганди в часи Голодомору 1932-1933 років доцільно розкривати, застосовуючи для цього й інші наочні прийоми організації інформації, зокрема вправу «Асоиіаиї̈». Пропонуємо учням назвати / написати асоціації до слів «інформація», «пропаганда», «фейк». Відповіді можна записувати на фліпчарті у три колонки або ж кожен учень записує на стікерах по 1-2 асоціації до кожного слова і кріпить їх на фліпчарті, коротко коментуючи свої варіанти. Вправу можна провести, використовуючи численні сучасні онлайн-інструменти, зокрема інтерактивну дошку Jamboard, сервіс для створення та проведення опитувань Mentimeter тощо.

Після обговорення відповідей учнів і співставлення їх із визначеннями наведених термінів, пропонуємо запитання для обговорення. Наприклад: «Чи можна вважати фейкові новини засобом пропаганди?», «Що $\epsilon$ спільного між фейками і пропагандою?». Зазвичай фейки асоціюються з нинішніми соціальними мережами. На вашу думку, чи могли поширюватися фейкові новини 85-90 років тому? Задля чого і яким чином це могло відбуватися? Як можна з'ясувати, що інформація $€$ неправдивою / фейковою? та ін.

У процесі вивчення означеної теми необхідно акцентувати увагу на ролі пропаганди, масмедіа в часи Голодомору, використовуючи для цього вправи, що мають на меті вироблення вмінь відрізняти інформацію від пропагандистських матеріалів. Наприклад, об'єднавши учнів у групи, можна запропонувати кожній групі по декілька цитат із закордонної та радянської преси і поставити завдання знайти та виокремити інформативні й фейкові / пропагандистські матеріали, пояснивши відповідно свою позицію. Деякі тематичні цитати, які можна використати, вміщені в авторській 
навчально-методичній розробці «Світ і Голодомор: інформація та пропаганда», опублікованій у журналі «Історія в рідній школі» № 1 за 2020 р. (Данильчук, Микитенко, 2020, с. 14-20).

Після завершення групової роботи 3 цитатами обов'язковим є обговорення. Орієнтовними можуть бути такі запитання: «Чи важко було відрізнити інформування від пропаганди? Чому?», «Яку роль відігравала пропаганда в умовах Голодомору?», «Чому тему голоду не порушували радянські журналісти?», «Що сталося 3 тими журналістами, які намагалися донести правду про Голодомор та події, що відбувалися в Радянській Україні? Наведіть приклади».

Вивчаючи представлену тему, необхідно робити наголос на тому, що Голодомор хоча й травмував, однак не зламав українського народу, адже 3-поміж мільйонів понівечених людських доль була значна кількість тих, хто не втратив людської гідності та віри й, усупереч несприятливим обставинам радянської дійсності наступних років, став художником, письменником, перекладачем, науковцем, громадським діячем, збагативши українську і світову культуру. Серед незламних героїв - автор Акта проголошення незалежності України у 1991 році Левко Лук'яненко, оперна співачка Євгенія Мірошниченко, дисиденти Іван Світличний та Олекса Тихий, видатна художниця Катерина Білокур, письменники Василь Барка, Олесь Гончар, лікарка Нонна Ауска, поет Дмитро Білоус, філософ Микола Руденко, кінодраматург Борис Хандрос, живописець Опанас Заливаха та багато інших (Проект «Незламні», 2016).

Для розвитку вміння встановлювати синхронність подій дієвою є робота зі стрічкою часу. Так, учням можна запропонувати у хронологічній послідовності розмістити на стрічці часу матеріали про події, які відбувалися у 30-х роках ХХ століття в Радянській та Західній Україні, у США і Західній Європі (світлини, цитати, документи, свідчення тощо). Для цього, об'єднуємо учнів у дві-три групи. Кожній із них пропонуємо набір ілюстративних матеріалів: першій групі - матеріали, які відображають події, що відбувалися в той час у Західній Україні; другій групі - матеріали, що стосуються Радянської України; третій групі - матеріали, що стосуються США та Західної Свропи. 3 метою наповнення вправи окремими краєзнавчими матеріалами, рекомендуємо скористатися книгою «Почутися одним нерозривним зі своїми братами і сестрами Великої України: відлуння Голодомору 1932-1933 pp. на Рівненщині» (Давидюк, Жив’юк, 2008). Стрічку часу можна створити у паперовому або онлайновому форматі.

Висновки. Таким чином, використовуючи представлений методичний інструментарій, ми розвиваємо критичне мислення учнів, що виявляється у визначенні характерних ознак явищ, подій, ідей, їхніх взаємозв'язків, умінні аналізувати та оцінювати доказовість і вагомість аргументів у судженнях, зважати на протилежні думки та контраргументи, розрізняти факти, їхні інтерпретації, розпізнавати спроби маніпулювання даними, використовуючи різноманітні ресурси і способи оцінювання якості доказів, надійності джерел і достовірності інформації. Однак при їхньому використанні важливим є розуміння, що очікуваних результатів в аспекті розвитку критичного мислення можна досягти лише за умови системної роботи й скрупульозного підбору методології.

Перспективи подалыших досліджень в означеному напрямі стосуватимуться проблем використання сучасних онлайн-інструментів у ході вивчення тематики Голодомору 1932-1933 років.

\section{СПИСОК ВИКОРИСТАНОЇ ЛІТЕРАТУРИ}

Нова українська школа. Концептуальні засади реформування середньої школи. (2016) / упоряд.: Л. Гриневич, О. Елькін та ін. Київ. 40 с.

Про освіту: Закон України. (2017). Законодавство України. URL: https://zakon.rada.gov.ua/laws/show/214519/paran186\#n186 (дата звернення: 08.09.2021).

Програми для загальноосвітніх навчальних закладів. Історія України. Всесвітня історія. 5-11 класи. (2018). URL: https://mon.gov.ua/ua/osvita/zagalnaserednya-osvita/navchalni-programi/navchalni-programidlya-10-11-klasiv (дата звернення: 10.09.2021).

Баханов, К. О. (2008). Технологія розвитку критичного мислення як психолого-педагогічне явище. Історія та правознавство. № 33 (169). С. 4-9.

Навчаємо мислити критично: посібник для вчителів. (2016) / автори-укладачі: О. І. Пометун, I. М. Сущенко. Дніпро: ЛІРА. 144 с.

Терно, С. О. (2011). Розвиток критичного мислення старшокласників у процесі навчання історії. Запоріжжя: ЗНУ. 275 с.

Курилів, В. (2008). Методика викладання історії. Харків-Торонто: ТОВ Вид-во «Ранок». 256 с.

Людяність у нелюдяний час. (2018) / упоряд. В. С. Тиліщак, В. М. Яременко. 2-ге вид., перероб. і доп. Київ: Смолоскип. 288 с.

Репресовані щоденники. Голодомор 1932-1933 років в Україні. (2018) / упоряд., вст. ст., заг. ред. Я. Файзуліна; УІНП. Київ: Фенікс. 352 с.

Гарет Джонс - журналіст, який першим розкрив правду про Голодомор 33-го року. (2017). URL: https:// www.youtube.com/watch?v=hjJ0iKJz2ns\&fbclid=IwAR0 URO5AQTaCgmQ2fFwvId1EQRIEVGhfwpb1O5Y2VNe Ph5LI (дата звернення: 12.09.2021).

Ціна правди: офіційний трейлер фільму. (2019). URL: https://www.youtube.com/watch?v=at21Noa_9kE (дата звернення: 12.09.2021).

Люди правди. Матеріали для завантаження. (2015) / Український інститут національної пам'яті. URL: https://old.uinp.gov.ua/page/lyudi-pravdi-materiali-dlyazavantazhennya (дата звернення: 10.09.2021).

Данильчук, В. Р., Микитенко, А. В. (2020). Світ і Голодомор. Інформація і пропаганда: навчально-методична розробка заняття з історії Голодомору 1932-1933 років. Історія в рідній школі. № 1 (221). С. 14-20.

Проект «Незламні». (2016) / Український інститут національної пам'яті. URL: https://old.uinp.gov.ua/page/ proekt-nezlamni (дата звернення: 08.09.2021).

Давидюк, Р. П., Жив’юк, А. А. (2008). Почутися одним нерозривним зі своїми братами і сестрами Великої України: відлуння Голодомору 1932-1933 рр. на Рівненщині. Рівне: ВААТ «Рівненська друкарня». 92 с. 


\section{REFERENCES}

Nova ukrainska shkola. Kontseptualni zasady reformuvannia serednoi shkoly [New Ukrainian School. Conceptual principles of secondary school reform]. (2016) / uporiad.: L. Hrynevych, O. Elkin ta in. Kyiv. 40 s. [in Ukrainian].

Pro osvitu: Zakon Ukrainy [On Education: Law of Ukraine]. (2017). Zakonodavstvo Ukrainy. URL: https:// zakon.rada.gov.ua/laws/show/2145-19/paran186\#n186 (data zvernennia: 08.09.2021). [in Ukrainian].

Prohramy dlia zahalnoosvitnikh navchalnykh zakladiv. Istoriia Ukrainy. Vsesvitnia istoriia. 5-11 klasy [Program for secondary schools History of Ukraine. World History. Grades 5-11]. (2018). URL: https://mon.gov.ua/ua/osvita/ zagalna-serednya-osvita/navchalni-programi/navchalniprogrami-dlya-10-11-klasiv (data zvernennia: 10.09.2021). [in Ukrainian].

Bakhanov, K. O. (2008). Tekhnolohiia rozvytku krytychnoho myslennia yak psykholoho-pedahohichne yavyshche [Technology of critical thinking development as a psychological and pedagogical phenomenon]. Istoriia ta pravoznavstvo. № 33 (169). S. 4-9. [in Ukrainian].

Navchaiemo myslyty krytychno [We teach to think critically]: posibnyk dlia vchyteliv. (2016) / avtory-ukladachi: O. I. Pometun, I. M. Sushchenko. Dnipro: LIRA. 144 s. [in Ukrainian].

Terno, S. O. (2011). Rozvytok krytychnoho myslennia starshoklasnykiv u protsesi navchannia istorii [Development of critical thinking of high school students in the process of teaching history]. Zaporizhzhia: ZNU. 275 s. [in Ukrainian].

Kuryliv, V. (2008). Metodyka vykladannia istorii [Methods of teaching history]. Kharkiv-Toronto: TOV Vyd-vo «Ranok». 256 s. [in Ukrainian].

Liudianist u neliudianyi chas [Humanity in inhuman times]. (2018) / uporiad. V. S. Tylishchak, V. M. Yaremenko. 2-he vyd., pererob. i dop. Kyiv: Smoloskyp. 288 s. [in Ukrainian].
Represovani shchodennyky. Holodomor 1932-1933 rokiv v Ukraini [Repressed diaries. The Holodomor of 1932-1933 in Ukraine]. (2018) / uporiad., vst. st., zah. red. Ya. Faizulina; UINP. Kyiv: Feniks. 352 s. [in Ukrainian].

Haret Dzhons - zhurnalist, yakyi pershym rozkryv pravdu pro Holodomor 33-ho roku [Gareth Jones journalist who first revealed the truth about the Holodomor of 1933]. (2017). URL: https://www.youtube.com/watch?v=hjJ0iKJz2ns\&fbclid=IwAR0URO5AQTaCgmQ2fFwvId1EQRIEVGhfwpb1O5OY2VNePh5LI (data zvernennia: 12.09.2021). [in Ukrainian].

Tsina pravdy [The price of truth]: ofitsiinyi treiler filmu. (2019). URL: https://www.youtube.com/watch?v=at21Noa_9kE (data zvernennia: 12.09.2021). [in Ukrainian].

Liudy pravdy [People of truth]: materialy dlia zavantazhennia. (2015) / Ukrainskyi instytut natsionalnoi pamiati. URL: https://old.uinp.gov.ua/page/lyudi-pravdi-materiali-dlya-zavantazhennya (data zvernennia: 10.09.2021). [in Ukrainian].

Danylchuk, V. R., Mykytenko, A. V. (2020). Svit i Holodomor. Informatsiia i propahanda [World and Holodomor. Information and propaganda]: navchalno-metodychna rozrobka zaniattia $\mathrm{z}$ istorii Holodomoru 1932-1933 rokiv. Istoriia $v$ ridnii shkoli. № 1 (221). S. 14-20. [in Ukrainian].

Proekt «Nezlamni» [Project «The Unbreakable»]. (2016) / Ukrainskyi instytut natsionalnoi pamiati. URL: https://old.uinp.gov.ua/page/proekt-nezlamni (data zvernennia: 08.09.2021). [in Ukrainian].

Davydiuk, R. P., Zhyviuk, A. A. (2008). Pochutysia odnym nerozryvnym zi svoimy bratamy i sestramy Velykoi Ukrainy: vidlunnia Holodomoru 1932-1933 rr. na Rivnenshchyni [Feeling inseparable from his brothers and sisters in Greater Ukraine: echoes of the Holodomor of 1932-1933 in Rivne Region]. Rivne: VAAT «Rivnenska drukarnia». 92 s. [in Ukrainian].

Дата надходження до редакиї: 19.09.2021 p. 